\title{
Influence of Different Soil Management Practices On Soil Properties and Its Implication on Soil Productivity
}

\author{
Mbah, C.N ${ }^{1}$., E. E. Attoe ${ }^{2}$ and U.F. Nwagu ${ }^{1}$ \\ ${ }^{I}$ Department of Soil Science and Environmental Management Ebonyi State University, Abakaliki,Ebonyi State, \\ Nigeria. \\ ${ }^{2}$ Department of Agronomy, Faculty of Agriculture, Cross River State University of Technology, Obubra \\ Campus, Cross River State, Nigeria.
}

\begin{abstract}
Soil management involves a lot of operation and practice. We studied the influence of different land management (use) practices; Golf course, (GC), Forest land (FL), Continuous Cropping (CL)) on soil properties. Soil samples were collected at 0-20cm, 20-40 cm and 40-60 cm depths from the different land use systems and analysed for exchangeable bases, total N\%, Om\%, Available P (ppm), bulk density (bd), total porosity (tp\%) and hydraulic conductivity (hc). Results of the study showed higher values of exchangeable bases in top 0-20cm compared to the values obtained in 20-40 cm and 40-60cm.Similarly, tp\% decreased with depth while bd and hc increased with depth in the different management systems,. Results showed higher mean values of Om\% in FL compared to GC and CL. Results of the study also showed little variability (1\%) to medium variability (48\%) in all parameters studied. Continuous cultivation was observed to deplete soil nutrient which could result to reduced soil productivity.
\end{abstract}

Keywords: Management Practice, Soil Properties, Soil Productivity and Variability

\section{Introduction}

Land use and anthropogenic management practices can influence soil properties. Some management practices lead to change in soil properties which predispose the soil to erosion. Lal (1982) $)^{1}$ observed that crop response to tillage practices is dependent on soil, climate and crop. According to Evanylo and McGuin (2000) ${ }^{2}$ management practices affect soil crusting and compaction, vegetative cover and soil porosity will increase or decrease the rate of infiltration. Johnson and Wolf $(1995)^{3}$ reported that in well aerated soil high doses of agricultural wastes resulted in the formation of large quantities of nitrates which according to Adams $(1994)^{4}$ is not fixed in appreciable quantities by soil and thus could be leached to the ground water. Gysi $(2001)^{5}$ observed that soil compaction has become a problem of worldwide concern especially under highly mechanised agricultural practices where severe structural degradation impedes plant growth. Stockdate et al., $(2001)^{6}$ and National Research Council (1989) $)^{7}$ observed that conventional management practices rely on the use of synthetic fertilizers, herbicides and pesticides for crop production and elimination of weeds and insects.

Research information on the properties of soils under different management or use is vital for proper management of tropical soils. This work primarily aims at evaluating the effect of different land use or management on soil properties in a Typic Haplustult in South-Eastern Nigeria. The specific objective of this work is to determine how the changes in soil properties due to land management system could affect soil productivity in a tropical Ultisol.

\subsection{Experimental site}

\section{Material and Methods}

The experiment was conducted at the faculty of Agriculture and Natural Research Management Farm complex, Ebonyi State University, Abakaliki. $\left(06^{0} 4^{1} \mathrm{~N}, 08^{0} 65^{1} \mathrm{E}\right)$. The area experiences bimodal pattern of rainfall and has a total annual rainfall varying between $1700-2000 \mathrm{~mm}$. It has a minimum temperature of $27^{\circ} \mathrm{c}$ and maximum temperature of $31^{\circ} \mathrm{c}$. The soil is a product of successive deposit from ASU river of crustaceous age belonging to the order Ultisol (FDALR, 1990) ${ }^{8}$ and classified as Typic Haplustult.

\subsection{Field methods}

Soil auger was used to collect samples from different land use systems namely forested land (FL), continuously cultivated land (CL) and golf site (GS). The samples were collected at the depths of $0-20 \mathrm{~cm}, 20$ $40 \mathrm{~cm}$ and $40-60 \mathrm{~cm}$ from each of the land use system. Three soil samples collected from each depth giving a total of 27 samples. The collected soil samples were air dried at room temperature preparatory for analysis. Similarly, core soil samples were collected for the determination of bulk density (Bd) and Hydraulic conductivity (Hc). 


\subsection{Laboratory analysis}

Bulk density was determined using the method described by Blake and Hartge, (1986) ${ }^{9}$. Total porosity was calculated from the dry bulk density data as fraction of total volume occupied by soil assuming a particle density of $2.65 \mathrm{mg}^{-3}$. Total nitrogen was determined by the Macro Kjeldah method (Bremmer, 1965) ${ }^{10}$. Available $\mathrm{P}$ was determined using Bray II as outlined in Page et al., (1982) ${ }^{11}$ and Organic Carbon by the Walkey and Black method (Nelson and Sommers, 1982) ${ }^{12}$. Soil $\mathrm{pH}$ in $\mathrm{Kcl}$ was by the glass electrode meter (Maclean, 1982) ${ }^{13}$. The exchangeable bases were determined by the method of Association of official Analytical chemists (AOAC, 1970) 14 $^{14}$

\subsection{Data Analysis}

The data collected were analysed using means and Coefficient of Variation (CV). Variability was ranked as follows. Little variation $(\mathrm{CV} \%<20 \%)$, moderate variation $(\mathrm{CV} \%>20 \%$ and $\leq 50 \%)$ and high variation $(\mathrm{CV} \%>50 \%)$ according to Aweto $(1982)^{14}$.

Table 1: Effect of different land use on soil bulk, total porosity, hydraulic conductivity

\begin{tabular}{|c|c|c|c|c|c|c|c|c|c|}
\hline \multirow[b]{2}{*}{ Depth $(\mathrm{cm})$} & \multicolumn{3}{|c|}{$\mathrm{Bd}$} & \multicolumn{3}{|c|}{$\mathrm{TP} \%$} & \multicolumn{3}{|c|}{$\mathrm{HC}$} \\
\hline & FL & GC & $C L$ & FL & GC & $\mathrm{CL}$ & FL & $\mathrm{GC}$ & $\mathrm{CL}$ \\
\hline $0-20$ & 1.40 & 1.46 & 1.30 & 47 & 54 & 31 & 45.1 & 45.7 & 49.0 \\
\hline $20-40$ & 1.45 & 1.76 & 1.32 & 45 & 34 & 50 & 40.3 & 40 & 47.3 \\
\hline $40-60$ & 1.45 & 1.77 & 1.35 & 45 & 34 & 49 & 43.8 & 44.1 & 48.5 \\
\hline Means & 1.42 & 1.66 & 1.32 & 46 & 38 & 50 & 43.0 & 46.3 & 48.2 \\
\hline CV\% & 9 & 2 & 6 & 7 & 12 & 10 & 4 & 7 & 3 \\
\hline
\end{tabular}

$\mathrm{FL}=$ Forest Land, $\mathrm{GC}=$ Golf course, $\mathrm{CL}=$ continuous Cultivated land, $\mathrm{Bd}=$ density, $\mathrm{Tp} \%=$ total porosity, $\mathrm{Hc}=$ hydraulic conductivity.

Table 2: Effect of different land use on soil $\mathrm{pH}, \mathrm{OM} \%$ total N\% and Available $\mathrm{P}(\mathrm{ppm})$

\begin{tabular}{|c|c|c|c|c|c|c|c|c|c|c|c|c|}
\hline & & $\mathrm{pH}$ & $\%$ & & & & 6 Totall & & & & vailable & \\
\hline Depths $(\mathrm{cm})$ & $\overline{F L}$ & $\mathrm{GC}$ & $\overline{\mathrm{CL}}$ & $\overline{F L}$ & $\mathrm{GC}$ & $\mathrm{CL}$ & FL & GC & $\overline{C L}$ & FL & GS & $\mathrm{CL}$ \\
\hline $0-20$ & 5.2 & 5.9 & 5.3 & 6.53 & 3.99 & 1.05 & 0.26 & 0.13 & 0.06 & 187 & 4.66 & 1.87 \\
\hline $20-40$ & 4.3 & 5.4 & 4.1 & 2.80 & 2.67 & 0.73 & 0.11 & 0.06 & 0.05 & 0.93 & 3.73 & 1.37 \\
\hline $40-60$ & 4.0 & 5.4 & 4.2 & 2.34 & 1.47 & 0.47 & 0.13 & 0.05 & 0.05 & 3.37 & 0.93 & 1.37 \\
\hline Means & 4.5 & 5.6 & 4.5 & 3.89 & 2.71 & 0.75 & 0.17 & 0.07 & 0.05 & 2.18 & 3.10 & 1.47 \\
\hline $\mathrm{C} \overline{\mathrm{V} \%}$ & 10 & 4 & 10 & 42 & 33 & 27 & 34 & 2 & 4 & 48 & 42 & $\overline{12}$ \\
\hline
\end{tabular}

$\mathrm{FL}=$ Forest Land, $\mathrm{GC}=$ Golf course, $\mathrm{CL}=$ continuous Cultivated land.

Table 3: Effect of different land use on soil exchangeable bases $\left(\mathrm{Cmolkg}^{-1}\right)$

\begin{tabular}{|c|c|c|c|c|c|c|c|c|c|c|c|c|}
\hline \multirow[b]{2}{*}{ Depths $(\mathrm{cm})$} & \multicolumn{2}{|l|}{$\mathrm{Na}^{+}$} & \multicolumn{3}{|c|}{$\mathrm{K}^{+}$} & \multicolumn{3}{|c|}{$\mathrm{Mg}^{2+}$} & \multicolumn{4}{|c|}{$\mathrm{Ca}^{2+}$} \\
\hline & FL & $\mathrm{GC}$ & $\mathrm{CL}$ & FL & GC & $\mathrm{CL}$ & FL & GC & CL & FL & GS & $\mathrm{CL}$ \\
\hline $0-20$ & 0.29 & 0.29 & 0.19 & 0.10 & 0.09 & 0.04 & 3.8 & 3.6 & 1.8 & 7.0 & 6.0 & 1.3 \\
\hline $20-40$ & 0.24 & 0.25 & 0.16 & 0.06 & 0.08 & 0.07 & 1.8 & 3.4 & 1.2 & 3.0 & 5.0 & 1.2 \\
\hline $40-60$ & 0.24 & 0.25 & 0.15 & 0.06 & 0.10 & 0.04 & 1.4 & 3.4 & .14 & 3.2 & 4.8 & 1.1 \\
\hline Means & 0.05 & & 0.61 & 0.07 & 0.09 & 0.05 & 2.3 & 3.5 & 1.5 & 4.4 & 5.3 & 1.2 \\
\hline $\mathrm{CV} \%$ & 18 & 33 & 10 & 24 & 8 & 24 & 40 & 2 & 23 & 36 & 19 & 1 \\
\hline
\end{tabular}

$\mathrm{FL}=$ Forest Land, $\mathrm{GC}=$ Golf course, $\mathrm{CL}=$ continuous Cultivated land.

\section{Results and Discussions}

Changes in the exchangeable bases of the different land management systems are shown in TABLE 1. In each of land use system top $0-20 \mathrm{~cm}$ depth had highest concentration of exchangeable bases $(\mathrm{Ca}, \mathrm{Mg}, \mathrm{K}, \mathrm{Na})$ compared to subsoil $(20-40 \mathrm{~cm}$ and $40-60 \mathrm{~cm})$. The magnitude of increase in each of the exchangeable bases was land management dependent. For example at the depth of $0-20 \mathrm{~cm}$, observed $\mathrm{Ca}$ value was $57 \%$ higher than $20-40 \mathrm{~cm}$ and $54 \%$ higher than $40-60 \mathrm{~cm}$ depth. The order of increase in $\mathrm{Mg}^{2+}$ content at $0-20 \mathrm{~cm}$ depth was $\mathrm{FL}>\mathrm{GC}>\mathrm{Cl}$. Observed values of $\mathrm{Na}$ and $\mathrm{K}$ also varied with depths in the studied land management systems with highest values obtained in the top $0-20 \mathrm{~cm}$ depth. The high levels of exchangeable bases observed at 
$0-20 \mathrm{~cm}$ depth relative to other depths could be attributed to higher levels of organic matter. Organic matter (OM) is reported to contribute to the CEC of soils that are low in clay. (Mbagwu et al., 1991) ${ }^{16}$. Coefficient of variation $(\mathrm{CV} \%)$ in the exchangeable bases ranged between $1-36 \%$ indicating little to moderate variation $(\text { Aweto, 1982) })^{15}$.

The $\mathrm{pH}$ of the studied soil ranged between $5.2-5.9$ in the top $0-20 \mathrm{~cm}$ and $4.0-5.4$ in the subsoil $(20-40 \mathrm{~cm}$, and $40-60 \mathrm{~cm})$ in the different land use systems (TABLE 2). These values indicated moderately acidic value in the top soil and extremely acidic value in the subsoil (USDA - SCS - 1974) $)^{17}$. Russel $(1977)^{18}$ argues that $\mathrm{pH}$ seems not to have a precise significance in agriculture due to various factors which affect the $\mathrm{pH}$ of the soil. However, some generalizations can nevertheless be made for interpretative purpose since crops have tolerance levels of soil $\mathrm{pH}$ and nutrient availability in soils. The table also show highest values of $\mathrm{OM} \%$ in the top $0-20 \mathrm{~cm}$ in all the land use systems. Observed $\mathrm{OM} \%$ values in top $0-20 \mathrm{~cm}$ of forest land (FL) was $57 \%$ higher than $20-40 \mathrm{~cm}$ and $64 \%$ higher than $40-60 \mathrm{~cm}$ depth. Available $\mathrm{P}$ was observed to vary in the order $\mathrm{GS}>\mathrm{FL}>\mathrm{CL}$ in the top $0-20 \mathrm{~cm}$ depth. Coefficient of variation (CV\%) in soil contents of $\mathrm{pH}, \% \mathrm{OM}, \mathrm{TN} \%$ and Available $\mathrm{P}(\mathrm{ppm})$ ranged between $2 \%$ - $48 \%$ across the different land management systems indicating little to moderate variability (Aweto, 1982$)^{15}$.

Results also shows that the different management techniques studied influenced the soil bulk density at all the depths (TABLE 3). Dry bulk density decreased in CL management technique by $18 \%$ for FL and 33\% for $\mathrm{GC}$ at $0-20 \mathrm{~cm}$ depths. The order of decrease in soil dry bulk density at the different depths of FL was $0-20 \mathrm{~cm}>$ $20-40 \mathrm{~cm}=40-60 \mathrm{~cm}$. Indirectly the decrease is a consequence of improved structure as is partly substantiated by an increase in total porosity.

The table also show decrease in total porosity (Tp) value with decrease in depth in all the studied land management system. The order of increase in mean values in $\mathrm{Tp}$ in the different land management systems was $\mathrm{CL}>\mathrm{FL}>\mathrm{GC}$. Observed values of hydraulic conductivity $(\mathrm{Hc})$ ranged from $45.1-49(0-20 \mathrm{~cm}), 40-47.3$ $(20-40 \mathrm{~cm})$ and $43.8-48.5(40-60 \mathrm{~cm})$ depths. The lower values of dry bd observed in the top $0-20 \mathrm{~cm}$ could be attributed to the direct and indirect effects of increased OM levels in the top soil (TABLE 2). The coefficient of variation in $\mathrm{Bd}, \mathrm{Tp}$ and $\mathrm{Hc}$ ranged from $2-12 \%$ indicating little to moderate variation. Alvaro et al., $(1998)^{19}$ observed that dry bulk density is a soil physical parameter used extensively to quantify soil compactness and has a very influential effect on root growth and proliferation which are both indicators of soil productivity Charau and Nicou $(1979)^{20}$ noted that a $0.1 \mathrm{mgm}^{-3}$ decrease in dry bulk density had a significant beneficial effect on root development and yield of sorghum and groundnut.

\section{Conclusion}

In conclusion, the average results of the study showed highest mean value of bulk density (bd) and Lowest mean values of other studied parameters in continuously cultivated lands (CL). This implies that continuous cultivation depletes soil nutrient which could lead to reduced soil productivity.

\section{References}

[1]. Lal, R. (1982). Tillage Research in the tropics. Soil Tillage Research. 2:305 -309.

[2]. Evanylo G. And McGuin R. (2000).Agricultural management practices and soil quality. Measuring, assessing and comparing laboratory and field test Klt indicators of soil quality attributes. Virginia co-operative Extension pub. No 452-460.

[3]. Johnson W. F. Jr and Wolf A. (1995). Nitrogen transformation in soils amended with poultry litter under aerobic conditions followed by anerobic periods. P27 - 34 in steel K (eds0. Animal wastes and the land - water interface. CRC press Boca Raton, Florida.

[4]. Adams P. C., Daneil, T. C. D. R., Edwards, D. J. Dote and Scott H. D. (1994). Poultry litter and manure contribution to nitrate leaching through Vadose Zone. Soil Science Amer. Journal 58:1206 - 1211.

[5]. FDALR (1985) Reconnaissance Soil Survey of Anambra State, Nigeria. Soil Report, FDALR,1985

[6]. Stockdate, A. E., N. H. La,pkin., Hovi., R. Keatinge., E. K. M. Lennartson, D. W. Macdonald., S. Padel., P. H. Tattorsall., M.S. Wolfe and Watson, C. A. (2001). Agronomic and environmental implications of organic farming systems. Adv. Agron 70:261-237.

[7]. National Research Council (1989). Alternative Agriculture. National Academy Press. Washington DC.

[8]. Gysi, E.A . (2001) Improvements in Aggregation and Infiltration of Characteristics of a Krasnozem under Maize with direct and stubble retention. Australian Journal of Soil Resoures.28: 577-590.

[9]. Blake G. R. And Hartge K. H. (1986). Bulk density: methods of soil analysis. Part 1: physical and mineralogical methods. Ed A. Klute pp 365-375. American society of Agronomy, Madison, W1. USA.

[10]. Bremmer M. (1965). Total Nitrogen. Methods of soil Analysis. Part II. Agronomy 9. Ed. C A. Black. Pp 1149-1198. Am. Soc. Agron. Madison. Wl.

[11]. Page, A. L., Miller, R. H. And Keeney, D. R (1982) Methods of soil analysis p: chemical and microbiological properties. ASA Madison.

[12]. Nelson, D. W. and Sommers, L. E. (1982). Total carbon, organic carbon and organic matter. Methods of soil analysis. Part 2: chemical and microbiological properties. ASA, Madison. Wl.pp 359-580.

[13]. Mclean E. O. (1982). Soil pH and line requirement. In methods of soil Analysis part II. Agronomy 9. Ed A. L. pp 199-234. Am Soc. Agron. Madison, W1. USA.

[14]. Association of Official Agricultural chemists, AOAC (1970). Official methods of Analysis II. Washington D.C.

[15]. Aweto A. O. (1982). Variability of upper slope soils development under sandstones in south-western Nigeria Geographic journal; $25: 27-37$. 
[16]. Mbagwu J.SC, P, ccolo A and Spallace, P. (1991) Effect of application of organic wastes on different surface soils. Biores Technol. 37:71-78.

[17]. USDA - SCS, (1974). Definitions and abbreviations for soil description, west technical service centre, Portland, Oregon, USA.

[18]. Ressel, E. W. (1977). Soil condition and plant growth $\left(10^{\text {th }}\right.$ Eds). Longman, London, UK $849 \mathrm{pp}$.

[19]. Alvaro, P. S., Kay B. D. And Perfect, E. (1998). Management versus inherent soil properties: effects on bulk density and relative compaction. Soil Tillage Research. 44:81-93.

[20]. Charau J. L. And Nicou, R. (1979). Root growth and development in sandy and sandy clay soils in Senegal. In soil physical properties and crop production in the tropics. Eds. R. Lal and D. J. Greenland pp 375-385. 